\title{
Morphological characteristics and morphometrics of Stingless Bees (Hymenoptera: Meliponini) in Yogyakarta, Indonesia
}

\author{
MANAP TRIANTO, HARI PURWANTO \\ Faculty of Biology, Universitas Gadjah Mada. Jl. Teknika Selatan, Sekip Utara, Bulaksumur, Sleman 55281,Yogyakarta, Indonesia. \\ Tel./fax.: +62-274-580839, `email: hari.purwanto@ugm.ac.id
}

Manuscript received: 28 November 2019. Revision accepted: 17 May 2020.

\begin{abstract}
Trianto M, Purwanto H. 2020. Morphological characteristics and morphometrics of Stingless Bees (Hymenoptera: Meliponini) in Yogyakarta, Indonesia. Biodiversitas 21: 2619-2628. Stingless bees (Apidae: Meliponinae) are eusocial insects living together in a colony with a highly organized system. Also, these bees have morphological and morphometric characters that vary among species, islands, and environmental types. This paper described morphological characteristics and morphometric study of stingless bees from the Special Region of Yogyakarta Province, Indonesia. There were seven species of stingless bees found in the Special Region of Yogyakarta, namely Tetragonula laeviceps, T. iridipennis, T. biroi, T. sapiens, T. sarawakensis, Lepidotrigona terminata, and Heterotrigona itama. The morphometry of the stingless bees obtained in this study has varying sizes compared to the same species that have been reported elsewhere. In this study, we described the morphological and morphometric characteristics of the seven species of stingless bees in the Special Region of Yogyakarta Province, Indonesia, and presented the PCA analysis to figure out the grouping characters in order to determine its diagnostic characters.
\end{abstract}

Keywords: Meliponini, morphological, morphometric, stingless bees, Yogyakarta

\section{INTRODUCTION}

Stingless bee (Hymenoptera: Meliponini) is a eusocial group insect that lives together in a nest (Michener 2007). This bee is instrumental in assisting the process of pollination (Free 1982; Inoue et al. 1985; Roubik 1989), a producer of honey and propolis (Lourino et al. 2006; Francoy 2009; Kumar et al. 2012). Although bees can produce valuable materials for people, there are still many people who ignore it.

Indonesia has many species of stingless bees that are widespread throughout the island (Rasmussen 2008). In Indonesia, there are at least 46 species of stingless bee scattered in several islands (Kahono et al. 2018). The diversity of stingless bees also varies in forest ecosystems and human settlements (Boontop et al. 2008; Salim et al. 2012; Kelly et al. 2014; Syafrizal et al. 2014; Rahman et al. 2015). In the settlement, a stingless bee nest can be found almost all parts of the house, ranging from the walls, the roof cavity, and the door cavity (Erniwati 2013).

Java is one of the islands with high levels of organism diversity (Kartikasari et al. 2012; Kusumaningrum and Prasetyo 2018). Information and publication on the existence of the stingless bees species in the Special Region of Yogyakarta are still lacking. Therefore, the exploration of stingless bees in the Special Region of Yogyakarta Province will provide new information on the diversity and distribution of the stingless bees.

Special Region of Yogyakarta is one of the provinces in Java that has many different environmental landscapes; plantations, agriculture lands, secondary forests, national parks, and settlements. In general, the people in this province prefer to keep Asian honey bees Apis cerana than stingless bee, because the honey bee can produce more honey. However, the current data showed that in Java and Indonesia in general, the interest of keeping stingless bees is increasing because keeping the stingless bees are more profitable. To support the success of stingless bees culture (Meliponiculture) in the Special Region of Yogyakarta Province, it is necessary to identify the species of stingless bees in that area. In this study, we explore the morphological and morphometric characteristics of stingless bees in the Special Region of Yogyakarta Province, Indonesia which local people (Java) known the stingless bee as "klanceng".

\section{MATERIALS AND METHODS}

\section{Study area}

This research was carried out from May-July 2019 in five district of Yogyakarta Province, Indonesia, namely Sleman, Bantul, Kulon Progo, Gunung Kidul, and Yogyakarta City (Figure 1).

\section{Procedures \\ Determination of sampling sites}

Sampling sites were established using a purposive sampling method (Bookhout 1996) reflecting the habitat diversity of Yogyakarta region. In total, there were 16 sampling sites covering Yogyakarta Province. On each of the sampling sites, ten observation points at $100 \mathrm{~m}$ distance of each other were determined. 

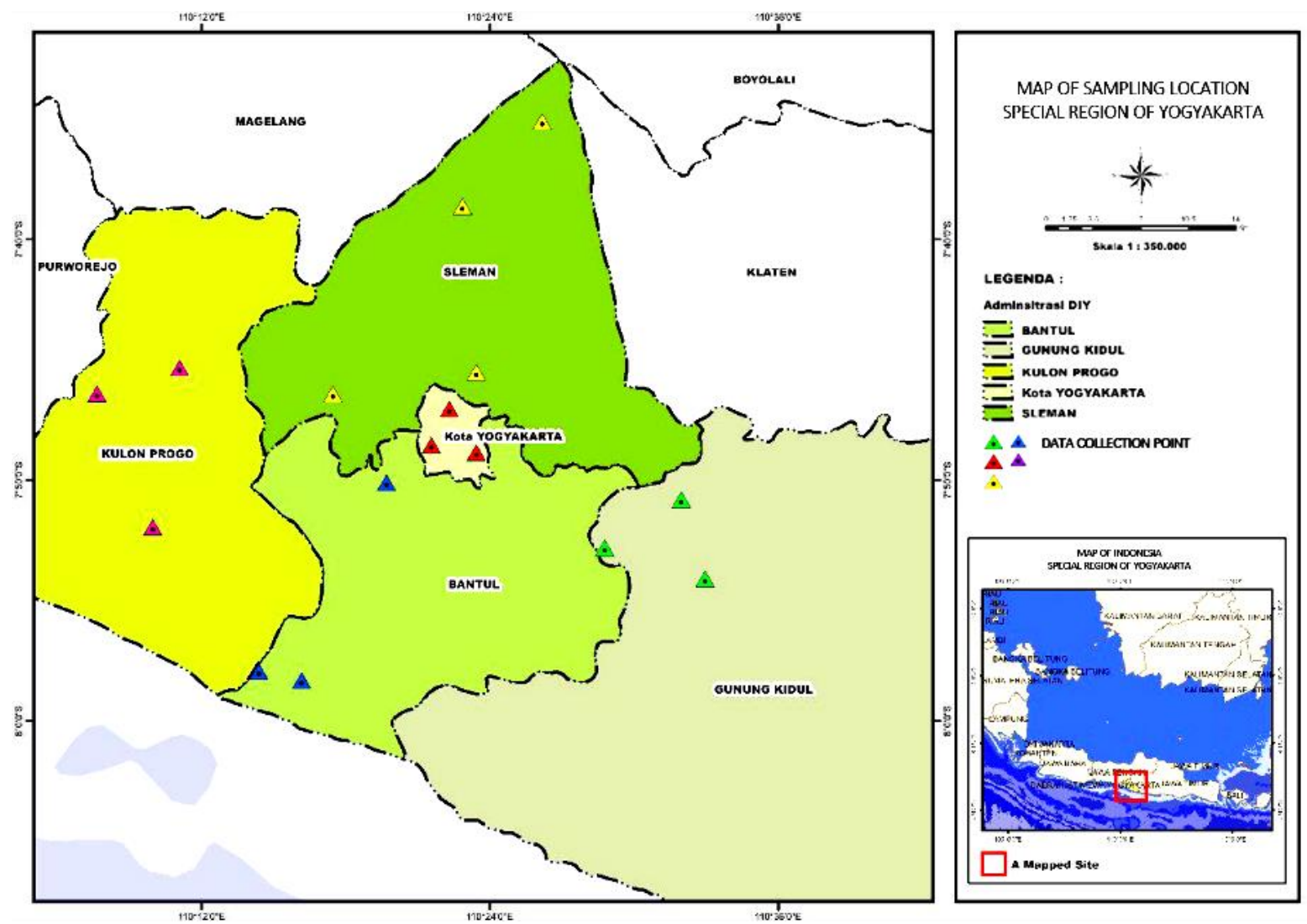

Figure 1. Study sites employed for the sampling of stingless bees in Yogyakarta, Indonesia

\section{Collection, preservation, and identification of stingless bees specimen}

The collection of the stingless bees was conducted on two consecutive days. At seven o'clock on the first day, a sugar solution was sprayed on one square meter shrubs at the determined observation points. On the second day, the stingless bees visiting the plot were captured using a sweep net. The catching activities were conducted three times per day at $07.00 \mathrm{am}, 13.00 \mathrm{pm}$, and $16.00 \mathrm{pm}$. The collection of the stingless bees is done on the second day, in order to provide more chances of stingless bees without sting coming to the study area. The collected samples put into a glass bottle with $90 \%$ ethanol.

The stingless bees specimens were identified in the laboratory of Entomology and Laboratory of Structure and Animal Development, Faculty of Biology, Universitas Gadjah Mada, Indonesia. Stingless bee specimens were identified based on morphological characters and morphometric measurements as described by Sakagami and Inoue (1987), Sakagami (1978), Dollin et al. (1997), Sakagami et al. (1990), Klakasikorn et al. (2005) and Smith (2012). Morphometric measurements were performed using a Microscope binokuler XSZ-107 BN with an Optilab viewer and Image Raster software.

\section{Data analysis}

The morphological and morphometric data acquired were then analyzed using Principal Component Analysis (PCA) with software PAST3 (Yudha et al. 2019). PCA analysis was conducted to figure out the grouping characters in order to determine its diagnostic characters. The characters used in this research are shown in Table 1.

\section{RESULTS AND DISCUSSION}

There are seven species of stingless bees belonging to three genera found in Yogyakarta, namely Tetragonula (5 species), Heterotrigona (1 species), and Lepidotrigona (1 species) (Figure 2).

\section{The Stingless bee morphology}

Tetragonula laeviceps (Smith 1857)

The body of the worker bee $T$. laeviceps is predominantly shiny black. The abdomen is blackish brown. Head is black, and is sparsely covered with white fine hairs. Compound eyes are reddish, ocelli are blackish and large. Clypeus is blackhead and fully covered with fine white hairs. Antennal has 11 flagellomeres, scape is yellowish-brown, socket is grey, pedicel brown, first flagellomere is brown, second to tenth flagellomeres are brown and slightly black. Mandible has two teeth, brown and slightly black at basal. Mesoscutum is black and is fully covered with yellowish setae, scutellum is black entirely, and is covered with yellowish setae at posterior. Tegula is brown and forewings coloration uniform. Hindwings are semi-transparent and wing venation is dark brown. Hind tibiae is short, corbicula is pear shape, 
sparsely is covered with long setae at apical but short at basal, entirely black and basitarsi is wholly black. First to sixth gastral tergites are fully brown and dark brown at dorsal part. The number of hamuli is 5 per hindwing (Figure 3.A-E).

\section{Tetragonula biroi (Friese 1898)}

The body of the worker bee $T$. biroi is predominantly black. The abdomen is blackish brown. Head is black, and is sparsely covered with brown fine hairs. Compound eyes and ocelli are brown. Clypeus is black and is fully covered with fine brown hairs. Antennal is with 11 flagellomeres, scape is yellowish-brown, socket is grey, pedicel is brown, first flagellomere is brown, second to tenth flagellomeres are brown and slightly black. Mandible is with two teeth, brown and slightly black at basal. Mesoscutum is black and is fully covered with testaceous setae, scutellum is black and covered with brown setae at posterior. Tegula is dark and basitarsi is wholly black. Wing venation is dark brown. Hind tibiae are entirely blackish, corbicula is pear shape, and basitarsi is wholly black. First to sixth gastral tergites are fully brown and dark brown at dorsal part. The number of hamuli is 5 per hindwing (Figure 4.A-E).

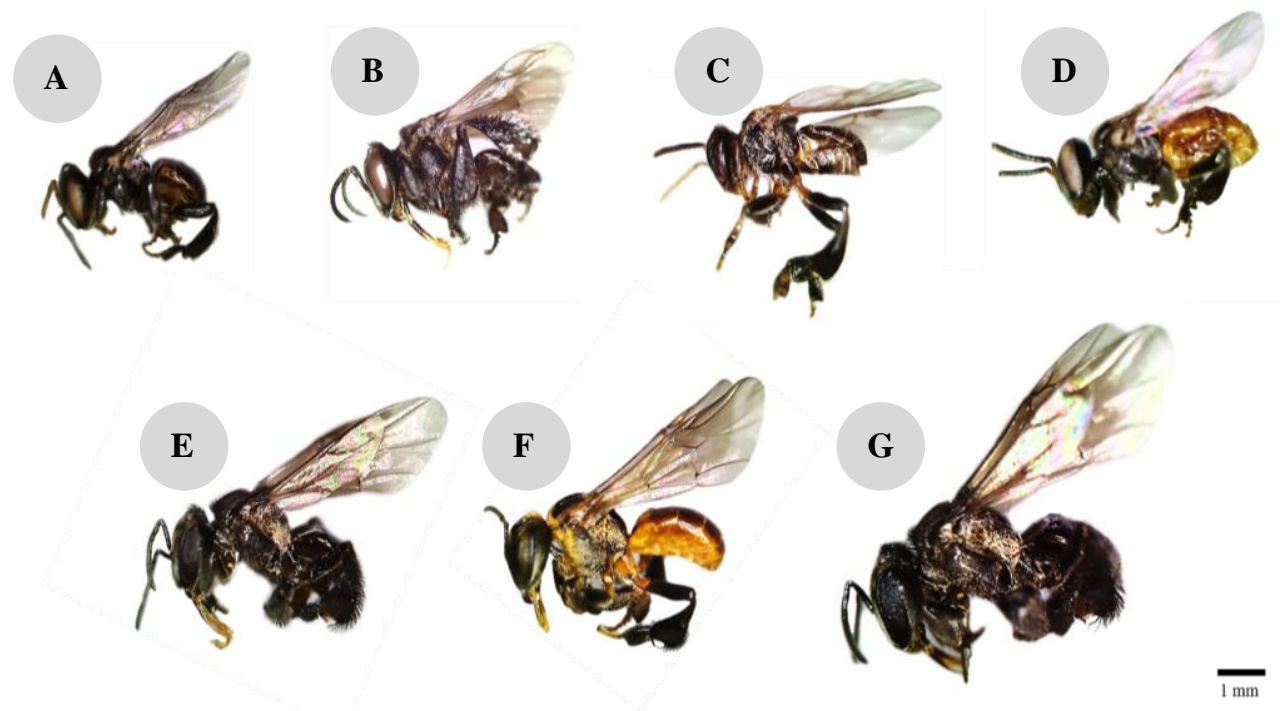

Figure 2. Stingless bee in Special Region of Yogyakarta Province, Indonesia: A. Tetragonula laeviceps, B. Tetragonula biroi, C. Tetragonula sapiens, D. Tetragonula sarawakensis, E. Tetragonula iridipennis, F. Lepidotrigona terminata, and G. Heterotrigona itama. Scale bar: $1 \mathrm{~mm}$

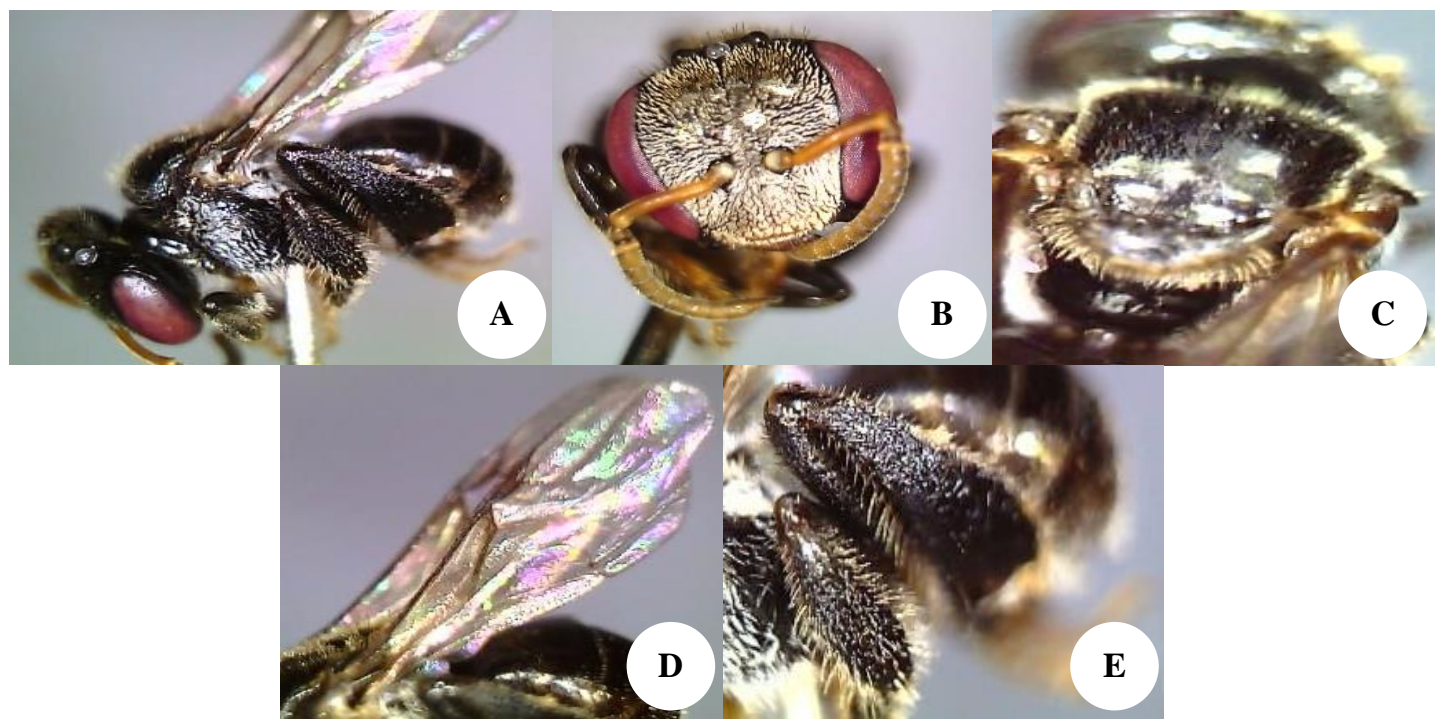

Figure 3. Tetragonula laeviceps; A. Habitus, lateral view; B. Frons; C. Mesoscutum; D. Forewing; E. Hind tibia and basitarsi. Scale bar: $1 \mathrm{~mm}$ 
Table 1. Morphometrics characters of stingless bees

\begin{tabular}{|c|c|c|c|c|c|c|c|c|c|c|c|c|c|c|}
\hline \multirow{3}{*}{ Body characters } & \multicolumn{14}{|c|}{ Morphometry of stingless bees $(\mathrm{mm})$} \\
\hline & \multicolumn{2}{|c|}{ T. laeviceps $(\mathrm{N}=48)$} & \multicolumn{2}{|c|}{ T. iridipennis $(\mathrm{N}=15)$} & \multicolumn{2}{|c|}{ T. biroi $(\mathrm{N}=5)$} & \multicolumn{2}{|c|}{ T. sapiens $(\mathbf{N}=8)$} & \multicolumn{2}{|c|}{ T. sarawakensis $(\mathrm{N}=3)$} & \multicolumn{2}{|c|}{ L. terminata $(\mathrm{N}=5)$} & \multicolumn{2}{|c|}{ H. itama $(\mathrm{N}=30)$} \\
\hline & Min-Max & Mean & Min-Max & Mean & Min-Max & Mean & Min-Max & Mean & Min-Max & Mean & Min-Max & Mean & Min-Max & Mean \\
\hline Body Lenght (BL) & $3.64-3.68$ & 3.65 & $3.73-3.75$ & 3.74 & $4.00-4.02$ & 4.00 & $3.75-3.77$ & 3.76 & $4.60-4.61$ & 4.60 & $4.63-4.64$ & 4.63 & $4.00-4.88$ & 4.84 \\
\hline Head Length (HL) & $1.35-1.38$ & 1.37 & $1.74-1.77$ & 1.75 & $1.48-1.49$ & 1.48 & $1.51-1.53$ & 1.52 & $1.64-1.66$ & 1.64 & $1.71-1.73$ & 1.72 & $1.48-2.01$ & 1.97 \\
\hline Head Width (HW) & $1.62-1.67$ & 1.65 & $1.56-1.59$ & 1.57 & $1.83-1.85$ & 1.84 & $1.60-1.80$ & 1.81 & $2.00-2.10$ & 2.10 & $2.23-2.26$ & 2.24 & $1.84-2.48$ & 2.43 \\
\hline Mandible Length (ML) & $0.60-0.65$ & 0.63 & $0.64-0.67$ & 0.65 & $0.50-0.60$ & 0.60 & $0.67-0.69$ & 0.68 & $0.70-0.71$ & 0.70 & $0.75-0.77$ & 0.76 & $0.60-0.93$ & 0.91 \\
\hline Mandible Widht (MW) & $0.20-0.24$ & 0.23 & $0.64-0.67$ & 0.24 & $0.24-0.25$ & 0.25 & $0.23-0.25$ & 0.24 & $0.24-0.25$ & 0.24 & $0.24-0.26$ & 0.25 & $0.24-0.26$ & 0.25 \\
\hline Clypeus Length (CL) & $0.42-0.47$ & 0.44 & $0.46-0.49$ & 0.48 & $0.48-0.49$ & 0.49 & $0.47-0.49$ & 0.48 & $0.53-0.54$ & 0.53 & $0.58-0.60$ & 0.59 & $0.49-0.65$ & 0.63 \\
\hline Lower Interocular Distance (LID) & $0.86-0.90$ & 0.88 & $0.99-1.02$ & 1.00 & 0.93-0.94 & 0.94 & $1.99-1.01$ & 1.00 & $1.26-1.27$ & 1.26 & $1.27-1.30$ & 1.28 & $0.94-1.32$ & 1.30 \\
\hline Upper Interocular Distance (UID) & $0.97-1.02$ & 1.00 & $1.06-1.09$ & 1.07 & $1.06-1.07$ & 1.07 & $1.06-1.08$ & 1.07 & $1.56-1.57$ & 1.56 & $1.57-1.59$ & 1.58 & $1.07-1.67$ & 1.64 \\
\hline Eye Width $(\mathrm{EW})$ & $0.35-0.46$ & 0.40 & $0.52-0.56$ & 0.54 & $0.50-0.50$ & 0.50 & $0.50-0.52$ & 0.51 & $0.50-0.51$ & 0.50 & $0.49-0.51$ & 0.50 & $0.50-0.61$ & 0.55 \\
\hline Eye Length (EL) & $1.00-1.04$ & 1.01 & $1.23-1.26$ & 1.25 & $1.30-1.30$ & 1.30 & $1.24-1.26$ & 1.25 & $1.37-1.38$ & 1.37 & $1.38-1.40$ & 1.39 & $1.30-1.44$ & 1.42 \\
\hline Maximum Interorbital Distance (MOD) & $1.05-1.21$ & 1.08 & $1.26-1.28$ & 1.27 & $1.22-1.23$ & 1.23 & $1.26-1.28$ & 1.27 & $1.62-1.63$ & 1.62 & $1.66-1.68$ & 1.67 & $1.23-1.74$ & 1.73 \\
\hline Lower Interorbital Distance (LOD) & $0.86-0.90$ & 0.88 & 0.96-0.99 & 0.98 & 0.93-0.94 & 0.94 & $0.97-0.99$ & 0.98 & $1.33-1.34$ & 1.33 & $1.40-1.42$ & 1.41 & $0.94-1.44$ & 1.46 \\
\hline Interantennal Distance (IAD) & $0.15-0.21$ & 0.19 & $0.16-0.19$ & 0.17 & $0.17-0.18$ & 0.18 & $0.16-0.18$ & 0.17 & $0.28-0$ & 0.28 & $0.29-0.31$ & 0.30 & $0.18-0.32$ & 0.31 \\
\hline Interocellar Distance (IOD) & $0.17-0.21$ & 0.20 & $0.20-0.23$ & 0.21 & $0.22-0.23$ & 0.23 & $0.21-0.23$ & 0.21 & $0.54-0.55$ & 0.54 & $0.60-0.62$ & 0.61 & $0.23-1.66$ & 0.66 \\
\hline Ocellocular Distance (OOD) & $0.20-0.24$ & 0.22 & $0.23-0.26$ & 0.24 & $0.23-0.24$ & 0.24 & $0.25-0.27$ & 0.26 & $0.42-0.43$ & 0.42 & .50 & 0.49 & $0.24-($ & 0.54 \\
\hline Antennocellar Distance (AD) & $0.61-0.64$ & 0.64 & $0.72-0.75$ & 0.73 & $0.68-0.69$ & 0.69 & $0.72-0.74$ & 0.73 & $0.65-0.66$ & 0.65 & $0.69-0.70$ & 0.70 & $0.69-0.74$ & 0.71 \\
\hline Antennocullar Distance (AOD) & $0.28-0.30$ & 0.29 & $0.30-0.32$ & 0.30 & $0.30-0.30$ & 0.30 & $0.30-0.32$ & 0.31 & $0.33-0.34$ & 0.34 & $0.41-0.42$ & 0.42 & $0.30-0.47$ & 0.46 \\
\hline Gena Width (GW) & $0.23-0.25$ & 0.23 & $0.23-0.26$ & 0.24 & $0.25-0.26$ & 0.26 & $0.23-0.25$ & 0.24 & $0.37-0.38$ & 0.37 & $0.38-0.39$ & 0.39 & $0.26-0.43$ & 0.41 \\
\hline Length of Flagellomere IV (FL) & $0.12-0.15$ & 0.12 & $0.14-0.16$ & 0.14 & $0.25-0.13$ & 0.13 & $0.13-0.15$ & 0.14 & $0.16-0.17$ & 0.16 & $0.16-0.17$ & 0.17 & $0.13-0.20$ & 0.18 \\
\hline Width of Flagellomere IV (FW) & $0.14-0.16$ & 0.14 & $0.12-0.15$ & 0.14 & $0.13-0.14$ & 0.14 & $0.13-0.15$ & 0.14 & $0.14-0.15$ & 0.14 & $0.13-0.14$ & 0.14 & $0.11-0.14$ & 0.14 \\
\hline Malar Length (ML) & 0.05-0.09 & 0.07 & $0.05-0.08$ & 0.06 & $0.04-0.04$ & 0.04 & $0.05-0.07$ & 0.06 & $0.11-0.12$ & 0.11 & $0.11-0.12$ & 0.12 & $0.04-0.15$ & 0.13 \\
\hline Mesoscutum Length (MCL) & $0.85-0.88$ & 0.86 & $0.92-0.95$ & 0.93 & $0.90-0.90$ & 0.90 & $0.92-0.94$ & 0.93 & -1.49 & 1.48 & $1.51-1.52$ & 1.52 & $0.90-1.58$ & 1.55 \\
\hline Mesoscutum Width (MCW) & $1.06-1.08$ & 1.06 & $1.20-1.50$ & 1.30 & $1.20-1.21$ & 1.21 & $1.29-1.31$ & 1.30 & $1.19-1.19$ & 1.19 & $1.22-1.23$ & 1.23 & $1.21-1.29$ & 1.27 \\
\hline Length of Forewing Including Tegula (WL1) & $3.60-3.65$ & 3.63 & $4.16-4.19$ & 4.17 & $4.15-4.16$ & 4.16 & 4.17-4.19 & 4.18 & $4.34-4.34$ & 4.34 & $5.54-5.55$ & 5.55 & $4.16-5.70$ & 5.67 \\
\hline Distance Between M-Cu Bifurcation (WL2) & $1.12-1.15$ & 1.13 & $1.25-1.28$ & 1.26 & $1.01-1.02$ & 1.02 & $1.10-1.20$ & 1.19 & $1.65-1.66$ & 1.66 & $1.66-1.67$ & 1.67 & $1.02-1.70$ & 1.68 \\
\hline Fore Wing Length (FWL) & $3.56-3.61$ & 3.58 & $3.73-3.76$ & 3.74 & $3.83-3.83$ & 3.83 & $3.90-3.92$ & 3.91 & $4.54-4.55$ & 4.55 & $5.26-5.27$ & 5.27 & $3.83-5.36$ & 5.33 \\
\hline Fore Wing Width (FWW) & $1.22-1.25$ & 1.22 & $1.45-1.46$ & 1.44 & $1.20-1.21$ & 1.21 & $1.20-1.40$ & 1.39 & $2.00-2.10$ & 2.00 & $2.20-2.01$ & 2.01 & $1.21-2.04$ & 2.01 \\
\hline Hind Wing Length (HWL) & $2.42-2.46$ & 2.43 & $2.70-2.72$ & 2.71 & $2.36-2.37$ & 2.37 & $2.69-2.71$ & 2.70 & $3.27-3.28$ & 3.28 & $3.96-3.97$ & 3.97 & $2.37-4.05$ & 4.02 \\
\hline Hind Wing Width (HWW) & $0.58-0.63$ & 0.59 & $0.62-0.65$ & 0.63 & $0.60-0.60$ & 0.60 & $0.60-0.62$ & 0.63 & $0.86-0.87$ & 0.87 & $0.90-0.90$ & 0.90 & $0.60-0.93$ & 0.92 \\
\hline Hamuli Number (HN) & 5 & 5 & 5 & 5 & 5 & 5 & 5 & 5 & 5 & 5 & 8 & 8 & 7 & 7 \\
\hline Hind Femur Length (HFL) & 0.96-0.99 & 0.98 & $1.15-1.18$ & 1.16 & $1.52-1.53$ & 1.53 & $1.13-1.15$ & 1.16 & $1.26-1.27$ & 1.27 & $1.22-1.22$ & 1.22 & $1.16-1.53$ & 1.17 \\
\hline Hind Tibia Width (HTW) & $0.43-0.47$ & 0.46 & $0.53-0.56$ & 0.54 & $0.52-0.53$ & 0.53 & $0.50-0.52$ & 0.51 & $0.61-0.62$ & 0.62 & $0.73-0.74$ & 0.74 & $0.53-0.79$ & 0.76 \\
\hline Hind Tibia Length (HTL) & $1.36-1.41$ & 1.39 & $1.73-1.76$ & 1.74 & $1.60-1.60$ & 1.60 & $0.72-0.74$ & 0.73 & $2.13-2.14$ & 2.14 & $2.14-2.15$ & 2.15 & $1.60-2.17$ & 2.16 \\
\hline Hind Basitarsus Width (HBV & $0.26-0.31$ & 0.28 & $0.33-0.35$ & 0.33 & $0.30-0.31$ & 0.31 & $0.30-0.32$ & 0.31 & $0.42-0.43$ & 0.43 & $0.46-0.47$ & 0.47 & $0.31-0.55$ & 0.53 \\
\hline Hind Basitarsus Length (HBL) & $0.56-0.62$ & 0.59 & $0.54-0.56$ & 0.55 & $0.58-0.58$ & 0.58 & $0.71-0.73$ & 0.72 & $0.67-0.68$ & 0.68 & $0.70-0.70$ & 0.70 & $0.58-0.79$ & 0.76 \\
\hline
\end{tabular}


Tetragonula sapiens (Cockerell 1911)

The body of the worker bee T. sapiens is black. The abdomen is brownish. Head is dark brown, and sparsely covered with yellow-brown fine hairs. Compound eyes and ocelli are dark browns. Clypeus is black and fully covered with fine testaceous hairs. Antennal is composed of 11 flagellomeres. Scape, socket, and flagellomere are yellowbrown. Mandible is with two teeth, brown and slightly black at basal. Mesoscutum is black, fully covered with dark brown setae, scutellum black, and covered with brown setae at posterior. Tegula and basitarsi are wholly dark brown. Wing venation is dark brown. Hind tibiae and basitarsi are entirely dark brown. First to sixth gastral tergites are fully brown and dark brown at dorsal part. The number of hamuli is 5 per hindwing (Figure 5.A-E).
Tetragonula sarawakensis (Schwarz 1939)

The body of the worker bee $T$. sarawakensis is predominantly black on the thorax and yellow on the abdomen. Head is dark brown, and is sparsely covered with yellow-brown fine hairs. Compound eyes and ocelli are brownish. Clypeus is blackhead and fully covered with fine brown hairs. Antennal is with 11 flagellomeres, scape, socket and flagellomere testaceous. Mandible is with two teeth, brown and slightly black at basal. Mesoscutum is black and, fully covered with dark brown setae, scutellum is black and covered with brown setae at posterior. Tegula is dark brown and basitarsi is wholly black. Wing venation is dark brown. Hind tibiae is entirely dark, corbicula is pear shape, and basitarsi wholly dark brown. The number of hamuli is 5 per hindwing (Figure 6.A-E).

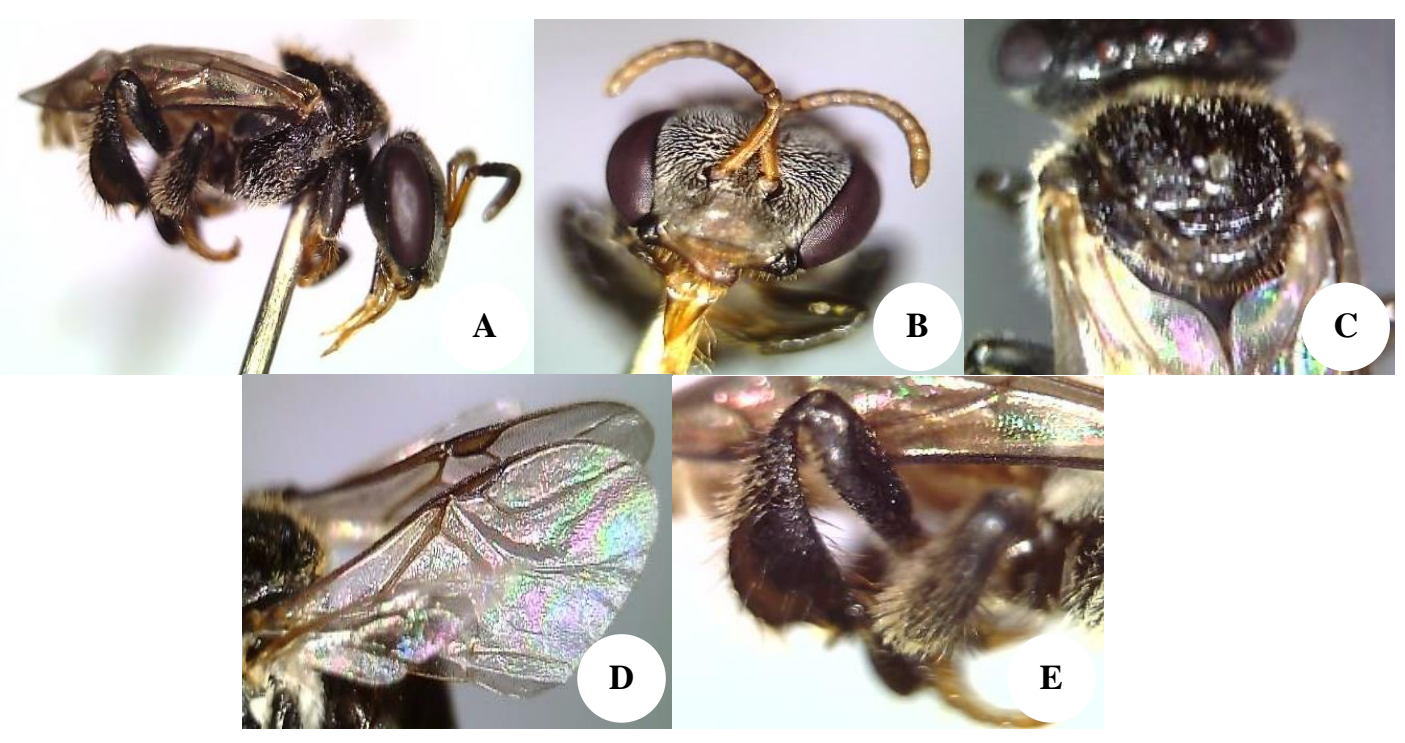

Figure 4. Tetragonula biroi; A. Habitus, lateral view; B. Frons; C. Mesoscutum; D. Forewing; E. Hind tibia and basitarsi. Scale bar: $1 \mathrm{~mm}$

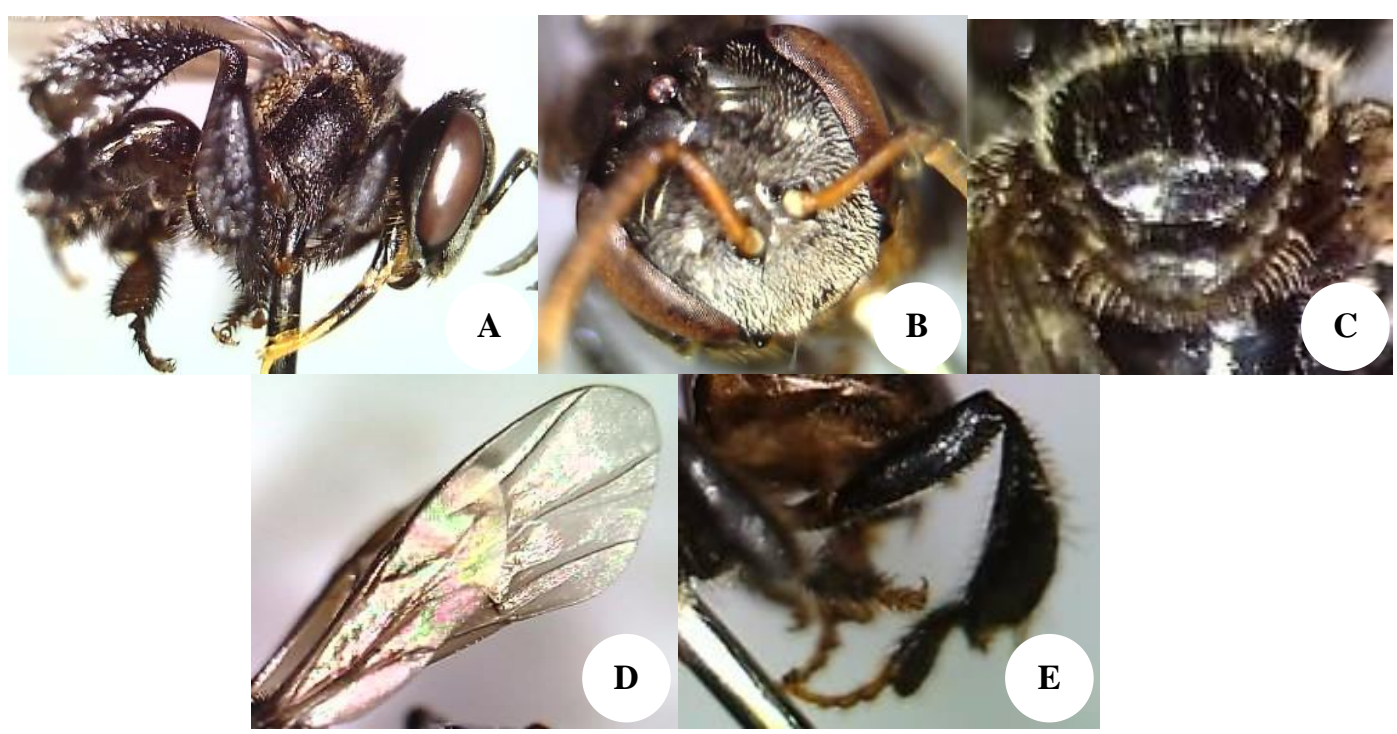

Figure 5. Tetragonula sapiens; A. Habitus, lateral view; B. Frons; C. Mesoscutum; D. Forewing; E. Hind tibia and basitarsi. Scale bar: 1 mm 


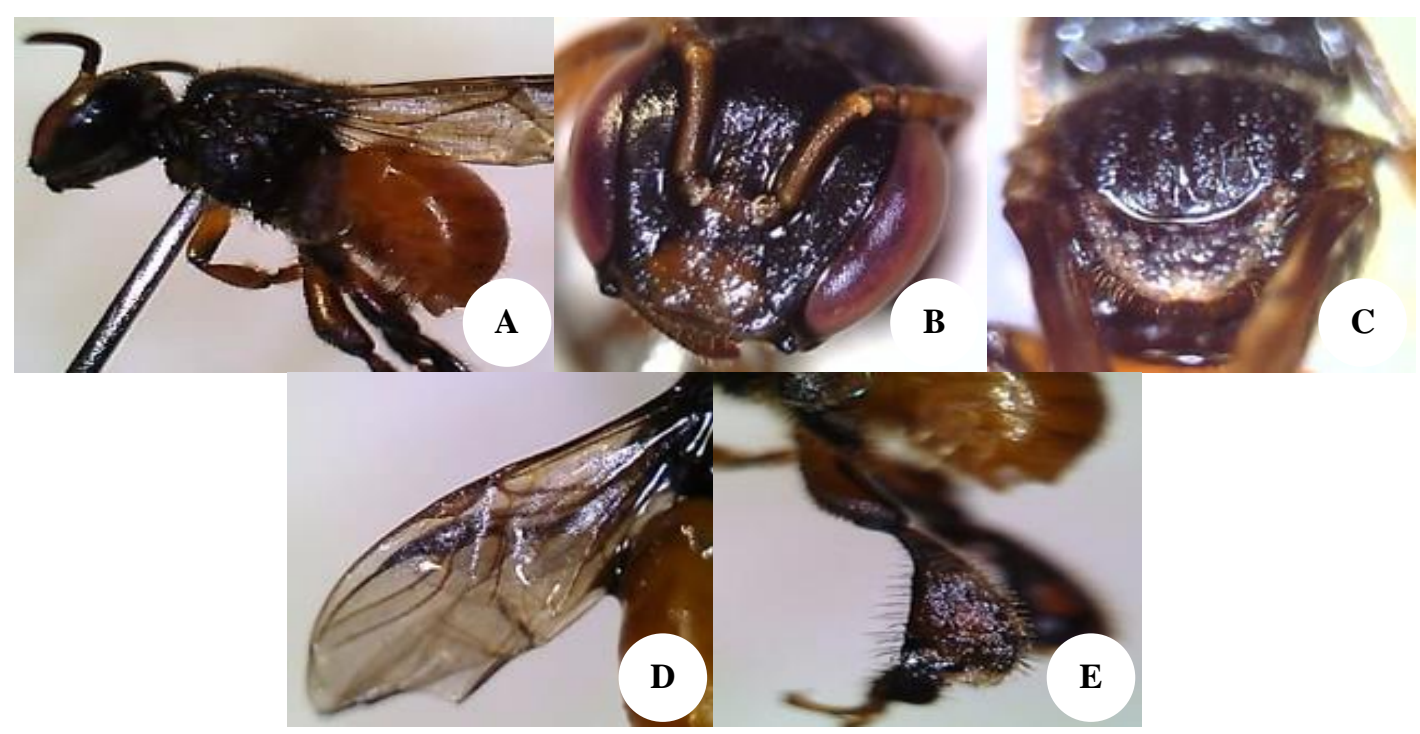

Figure 6. Tetragonula sarawakensis; A. Habitus, lateral view; B. Frons; C. Mesoscutum; D. Forewing; E. Hind tibia and basitarsi. Scale bar: $1 \mathrm{~mm}$

\section{Tetragonula iridipennis (Smith 1857)}

The body of the worker bee $T$. iridipennis is predominantly blackish brown. The abdomen is dark brown. Head is dark brown and is sparsely covered with yellowish-brown hairs. Compound eyes is brown, and ocelli are brown and large. Clypeus is blackish and covered with white to brownish hairs. Antennal is with 11 flagellomeres, socket is grey to blackish, scape is brown, pedicel, and entire flagella are brown to blackish. Mandible has two teeth, is brown but black at basal, and slightly black at apical. Mesoscutum is black and is covered with yellow to blackish brown setae. Scutellum is blackish brown to black entirely and covered with yellowish to blackish brown setae. Tegulae is dark brown, uniform coloration of forewings and hindwings are semitransparent. Hind tibiae are blackish-brown and basitarsi is blackish brown to black. The number of hamuli is 5 per hindwing (Figure 7.A-E).

\section{Lepidotrigona terminata (Smith 1857)}

The body of the worker bee $L$. terminata is predominantly black. The abdomen is darkbrown. Head black and frons are fully covered with fine white hairs. Compound eyes are blackish and ocelli are blackish and large. Clypeus is black and fully covered with fine white hairs. Antennal is composed of 11 flagellomeres, sockets are yellowish-grey, scape is black but brown at basal, pedicel, and flagella are blackish-brown entirely. The mandible has two small teeth, black at basal half and brown on the other half. Mesoscutum is wholly black, frame is with a thick golden yellow scalelike and is covered with brown setae at anterior margin. Scutellum is black entirely, frame is with a golden yellow scale-like at the posterior margin and covered with brown setae. Tegulae is dark brown, uniform coloration of forewings and hindwings are semi-transparent. Hind tibiae and basitarsus are black entirely. The number of hamuli is 8 per hindwing (Figure 8.A-E).

\section{Heterotrigona itama (Cockerell 1911)}

The body of the worker bee H. itama is predominantly dark black. The abdomen is dark black. Head is black, frons are fully covered with fine white hair, and are slightly thick white hairs approaching clypeus. Compound eyes and ocelli are blackish. Clypeus is black and fully covered with white hair. Antennal is composed of 11 flagellomeres, sockets are grey, scape is black and brown at basal part, pedicel and entire flagella are completely black. The mandible has one teeth and is entirely black. Mesoscutum and scutellum are wholly black. Tegulae is dark black. Forewings and hindwings are black, wing venation is dark brown and semi-transparent. Hind tibiae and basitarsi are entirely black. The number of hamuli is 7 per hindwing (Figure 9.A-E).

\section{The Stingless bee morphometrics}

The morphometry of the seven species of stingless bees obtained has a variety of sizes (Table 1).

Furthermore, the morphometric data is analyzed using the principal component analysis to see the dominant character affect variation of the clustering pattern of individuals (seven species) of stingless bees. Principal Component Analysis (PCA) was conducted from the data collected. The correlation analysis between-group results in eigenvalues and percent variances shown in Table 2, while the scatter plot can be seen in Figure 10.

Table 2. Eigenvalue and \% Variance

\begin{tabular}{lcc}
\hline PC & Eigenvalue & \% Variance \\
\hline 1 & 3.00597 & 95.053 \\
2 & 0.06071 & 1.9199 \\
3 & 0.04620 & 1.4609 \\
4 & 0.02103 & 0.6650 \\
5 & 0.01439 & 0.4551 \\
\hline
\end{tabular}


The principal components analysis shows the pattern of sample clustering based on the role of each character in the clustering process. The loading plot of component 1 can be seen in Figure 11, while the loading plot component 2 can be seen in Figure 12. Of the 114 individual stingless bees analyzed, seven groups formed according to the species, namely $T$. laeviceps, $T$. iridipennis, $T$. biroi, $T$. sapiens, $T$. sarawakensis, L. terminata, and H. itama groups.

\section{Discussion}

The morphological characters of the $T$. laeviceps worker bees from this study have morphological characteristics that are in accordance with the description of Sakagami (1978), Sakagami et al. (1990), Rasmussen and Michener (2010), Smith (2012), Suriawanto (2016), Karimah et al. (2017), Efin et al. (2019) and Manarudin (2019). T. laeviceps specimens from Special Region of Yogyakarta in this study have a body size (3.64-3.68 mm), shorter than the specimens described by Sakagami (1978) that was using samples from Asia and Sri Lanka (4.0-4.6 $\mathrm{mm}$ ) and Efin et al. (2019) that used specimens from Banten (4.31-4.58). Meanwhile, when compared with the data by Rasmussen and Michener (2010) and Smith (2012), who used samples from Singapore $(3.50 \mathrm{~mm})$ and Suriawanto (2016) who used specimens from Sulawesi $(3.40-3.43 \mathrm{~mm})$, the specimen in this study had a longer body size.

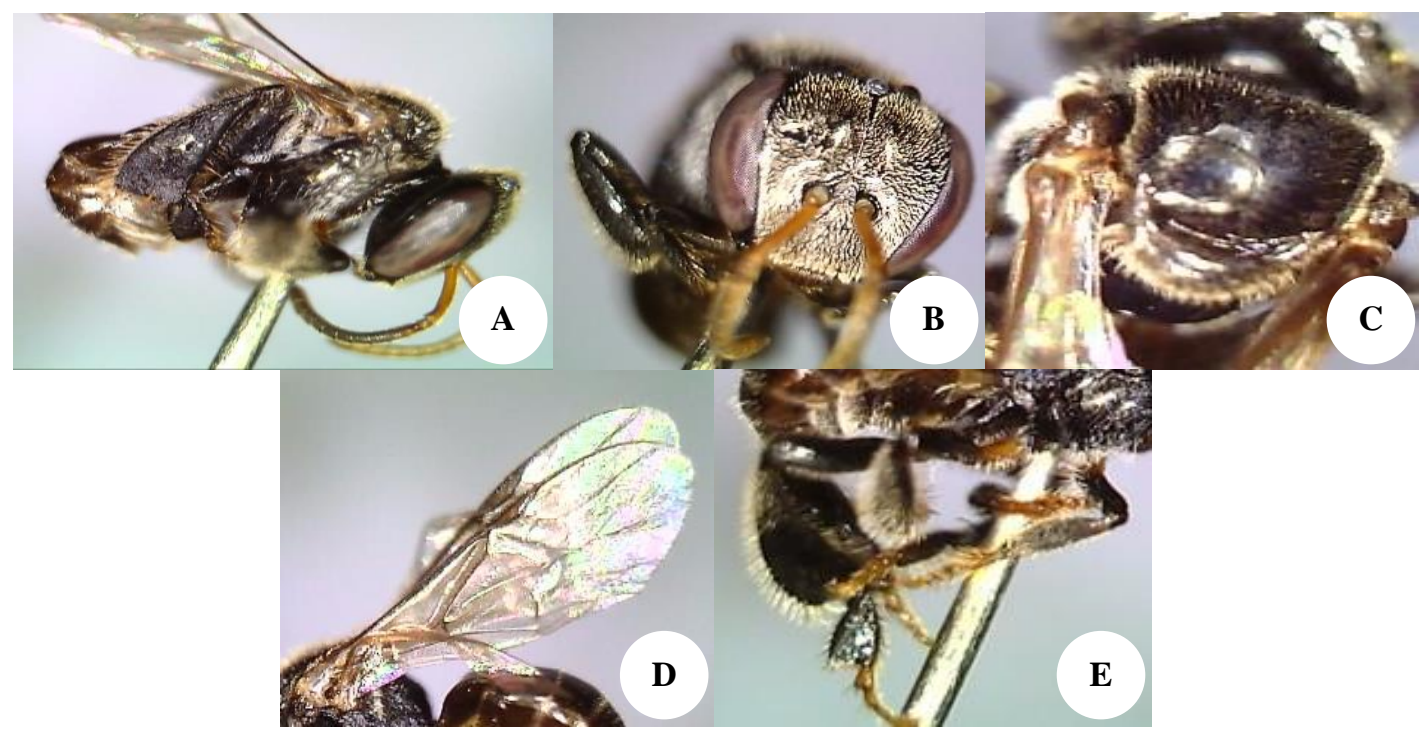

Figure 7. Tetragonula iridipennis; A. Habitus, lateral view; B. Frons; C. Mesoscutum; D. Forewing; E. Hind tibia and basitarsi. Scale bar: $1 \mathrm{~mm}$

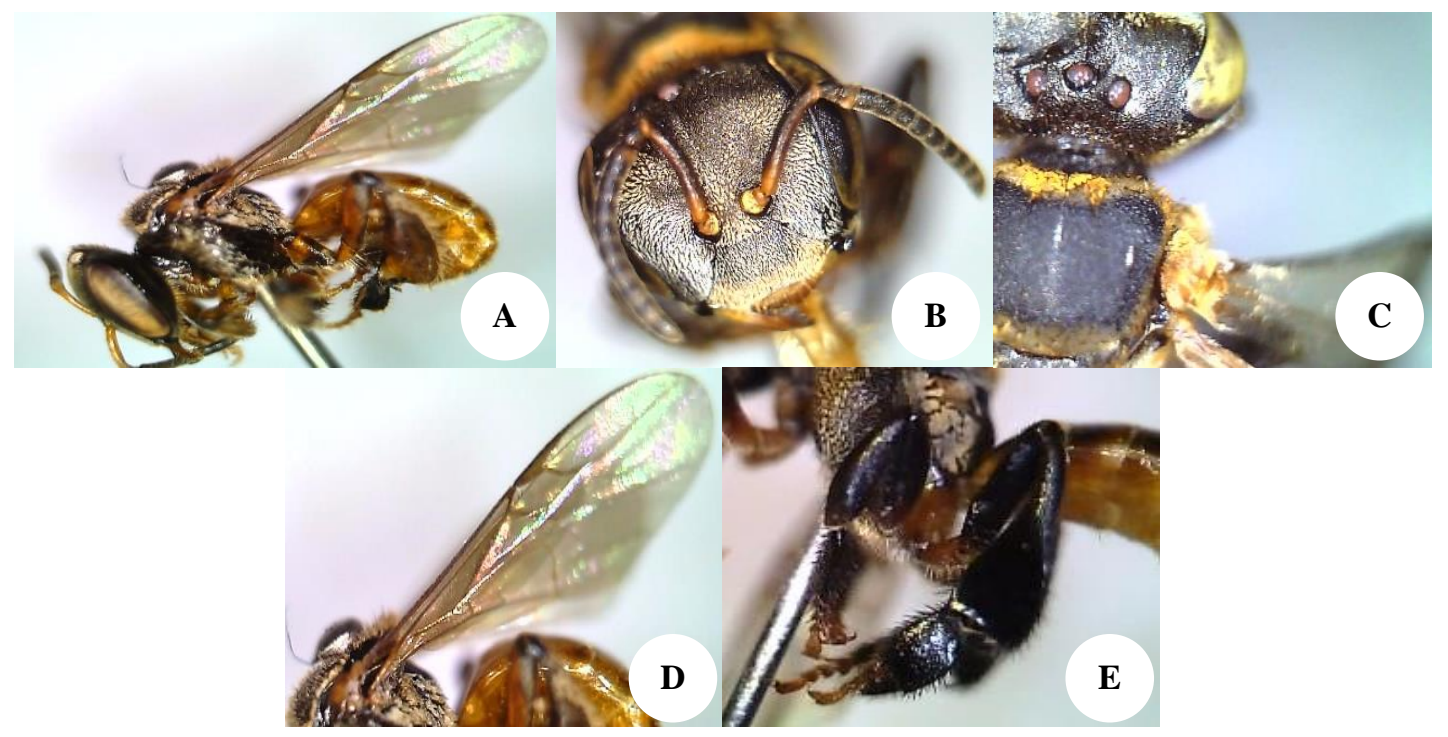

Figure 8. Lepidotrigona terminata; A. Habitus, lateral view; B. Frons; C. Mesoscutum; D. Forewing; E. Hind tibia and basitarsi. Scale bar: $1 \mathrm{~mm}$ 


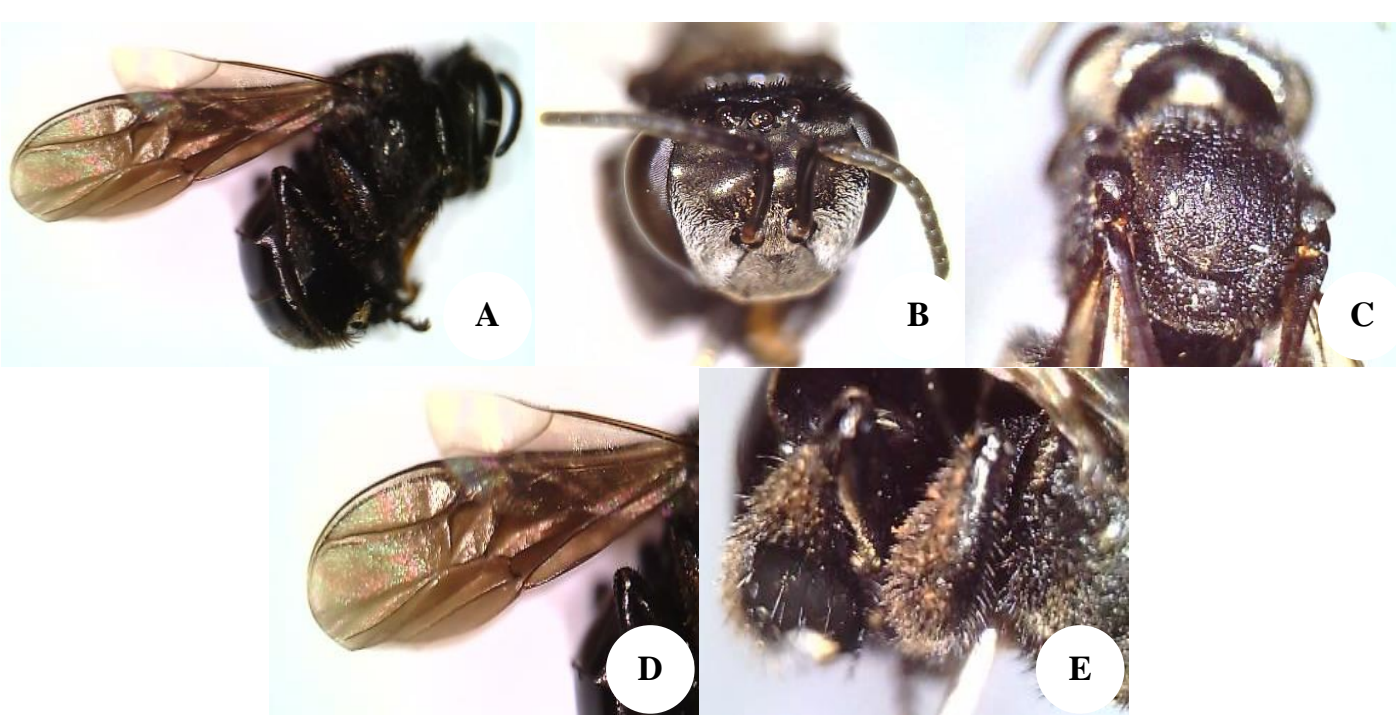

Figure 9. Heterotrigona itama; A. Habitus, lateral view; B. Frons; C. Mesoscutum; D. Forewing; E. Hind tibia and basitarsi. Scale bar: $1 \mathrm{~mm}$

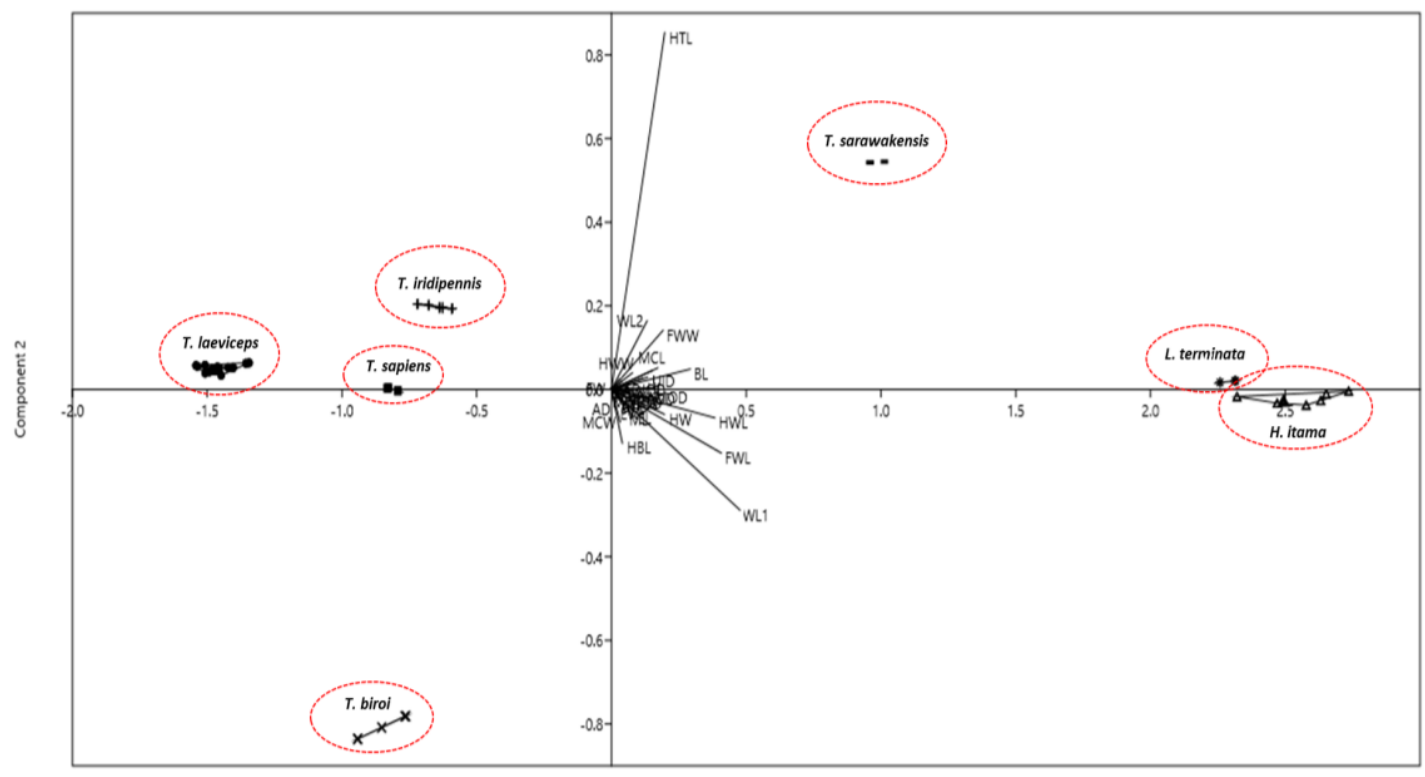

Figure 10. The PCA results of stingless bees

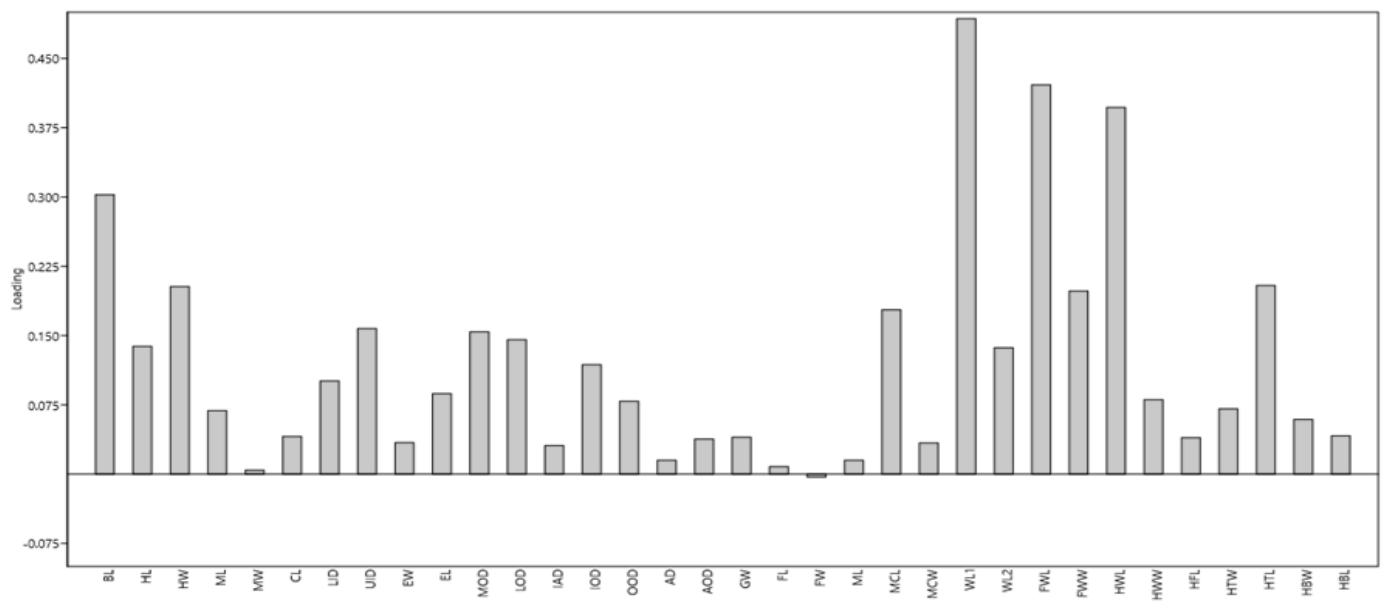

Figure 11. The loading plot of component 1 


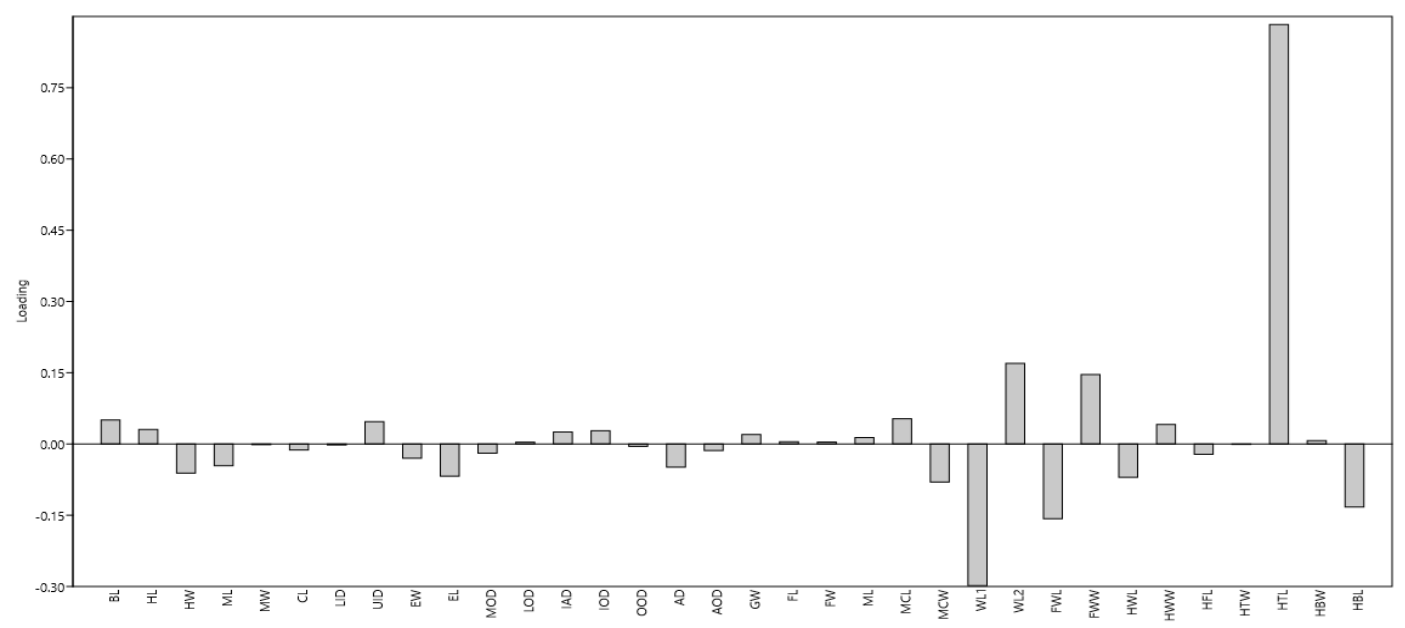

Figure 12. The loading plot of component 2

The workers of $T$. iridipennis described in this study are similar to the description of Schwarz (1939), Sakagami (1978), Nugroho (2013), Vijayakumar et al. (2014), Tej et al. (2017), and Daniswara and Sudaryadi (2018). However, the fore wing length of $T$. iridipennis in this study (3.73$3.76 \mathrm{~mm}$ ) is longer compared to the specimens from India (3.45 mm) used by Tej et al. (2017).

The morphology of the T. biroi worker bee is similar to that of $T$. iridipennis, which has a reduced malar space but can still be seen as the distance between the compound eyes and the mandible. Black hairs in the mesoscutum and mesoscutellum are special characters in T. biroi (Schwarz 1939; Sakagami 1978; Vijayakumar et al. 2014; Suriawanto 2016). T. biroi reported by Schwarz (1939) and Smith (2012) has fore wing length of 4.2 and $4.4 \mathrm{~mm}$, whereas in this study the specimens have shorter fore wing (3.83 mm).

The morphology of the T. sapiens worker bees described in this study is in accordance with those described by Dollin et al. (1997) and Suriawanto (2016). The fore wing length of $T$. sapiens in this study (3.90-3.92 $\mathrm{mm}$ ) is shorter than the sample of Papua New Guinea (4.2$4.5 \mathrm{~mm}$ ) and Solomon Island (4.2-4.5 mm) reported by Dollin et al. (1997). The morphology of the T. sapiens described in this study is in accordance with samples from South Sulawesi. Previously, the T. sapiens have never been reported in Java, but it occurs in Wallacea area, Papua, Australia, Salomon Island, and the Philippines. We had information from beekeepers in Yogyakarta that this species was imported from Lombok (NTB). Therefore, we suspect that the $T$. sapiens collected during this study is an introduced species.

The workers bees of $T$. sarawakensis of this study have similar morphological characters with the description of Schwarz (1939), Moure (1961), Sakagami (1978), Sakagami and Inoue (1987) and Sakagami et al. (1990). The body length of $T$. sarawakensis in this study (4.60-4.61 $\mathrm{mm}$ ) is shorter compared to those samples from Malaysia
(6.13-7.35 mm) used by Rasmussen and Cameron (2007), and the hind tibia length $T$. sarawakensis in this study $(2.13-2.14 \mathrm{~mm})$ is also shorter than specimens from Malaysia (3.06-3.18 mm).

The worker bee L. terminata of this study has similar morphological characters and morphometrics with specimen from Myanmar described by Smith (1878) and from Malaysia reported by Rasmussen and Cameron (2007). The morphology of the H. itama worker bees described in this study is similar to the description of Cockerell (1918) and Schwarz (1939). The body size of $H$. itama in this study $(4.00-4.88 \mathrm{~mm})$ is relatively shorter than the specimen from Malaysia (4.78-7.85 $\mathrm{mm}$ ) by Rasmussen and Cameron (2007). Furthermore, the length (1.60-2.17 $\mathrm{mm})$ and width of the tibia $(0.53-0.79 \mathrm{~mm})$ of the specimens in this study are also relatively shorter than samples from Malaysia, 2.00-2.90 $\mathrm{mm}$ for the length and $0.78-1.11 \mathrm{~mm}$ for the tibia width.

Based on the results of PCA, there are variations of individual stingless bees measurements. The most dominant characters for the formation of seven clusters that determine to cluster the species is the Hind Tibia Length (HTL), followed by Length of Forewing Including Tegula (WL1), Fore Wing Length (FWL), Hind Wing Length (HWL), and Body Length (BL). This can be seen from the length of the resulted line (Figure 10), and also the picture of Loading Plot of Component 1 (Figure 11) and Loading Plot of Component 2 (Figure 12) produced. The longer the arrow and the higher the graph formed, hence the characters' role in group formation is also high.

In conclusion, all stingless bees found in this study are new records for the Special Region of Yogyakarta Province and the body size of different worker bees is generally considered a form of adaptation in foraging activities and exploiting flower resources. The research data are expected to contribute to the preservation and utilization of one of Indonesia's important biodiversity resources. 


\section{ACKNOWLEDGEMENTS}

This work was supported by Universitas Gadjah Mada Research grant with the scheme of the Final Assignment Recognition (RTA) Program 2019. We would like to thanks to our colleagues (Moh Fajar Farid, Sukmawati, Fajri Marisa, Moh. Dahri Kisman, and Herlangga Adi Putra) who help on data sampling and also staffs from the Laboratory of Entomology and Laboratory of Structure and Animal Development, Faculty of Biology, Universitas Gadjah Mada, Yogyakarta, Indonesia for providing facilities during the research.

\section{REFERENCES}

Bookhout TA. 1996. Research and Management Techniques for Wildlife and Habitats. Allen Press Inc, Kansas, USA.

Boontop Y, Malaipan S, Chareansom K, Wiwatwittaya D. 2008. Diversity of stingless bees (Apidae: Meliponini) in Thong Pha Phum District, Kanchanaburi Province, Thailand. Kas J Nat Sci 42: 444-456.

Cockerell TDA. 1918. Descriptions and records of bees-LXXX. J Nat Hist 2: 384-390.

Daniswara P, Sudaryadi I. 2018. Keanekaragaman Sumber Pakan dan Perilaku Mencari Pakan Tetragonula iridipennis Smith, 1854 (Hymenoptera: Apidae) di Kawasan Gunung Merapi, Sleman, Yogyakarta. [Dissertation]. Universitas Gadjah Mada, Yogyakarta. [Indonesian]

Dollin AE, Dollin LJ, Sakagami SF. 1997. Australian stingless bees of the genus Trigona (Hymenoptera: Apidae). Invertebr Syst 11: 861-896.

Efin A, Atmowidi T, Prawasti TS. 2019. Morphological characteristics and morphometric of stingless bee (Apidae: Hymenoptera) from Banten Province, Indonesia. Biodiversitas 20: 1693-1698.

Erniwati. 2013. Kajian biologi lebah tak bersengat (Apidae: Trigona) di Indonesia. Fauna Indonesia 12: 29-34. [Indonesian]

Francoy TM. 2009. Gender identification of five genera of stingless bees (Apidae, Meliponini) based on wing morphology. Genet Mol Res 8: 207-214.

Free JB. 1982. Bees and Mankind. George Allen \& Unwin, London (GB).

Inoue T, Salamah S, Abbas I, Yusuf E. 1985. Foraging behaviour of individual workers and foraging dynamics of colonies of three Sumatran stingless bees. Res Popul Ecol 27: 373-392.

Kahono S, Chantawannakul P, Engel MS. 2018. Social bees and the current status of beekeeping in Indonesia. In: Chantawannakul P, Williams G, Neumann P (eds). Asian Beekeeping in the 21st Century. Springer Verlag, Berlin.

Karimah KN. 2017. Morfologi dan struktur sarang Tetragonula laeviceps (Apidae: Meliponinae) asal Subang dan Sukabumi, Jawa Barat. [Thesis]. Institut Pertanian Bogor, Bogor. [Indonesian]

Kartikasari SN, Marshall AJ, Beehler BM. 2012. Ekologi Indonesia. Jilid VI. Periplus Editions and Conservation International, Jakarta. [Indonesian]

Kelly N, Farisya MSN, Kumara TK, Marcela P. 2014. Species diversity and external nest characteristics of stingless bees in meliponiculture. Pertanika J Trop Agric Sci 37: 293-298.

Klakasikorn A, Wongsiri S, Deowanish S, Duangphakdee O. 2005. New record of stingless bees (Meliponini: Trigona) in Thailand. Nat Hist J Chulalongkorn Univ 5: 1-7

Kumar MS, Singh AJAR, Alagumuthu G. 2012. Traditional beeskeeping of stingless bees (Trigona sp.) by Kani tribes of Western Ghats, Tamil Nadu, India. Indian J Tradit Knowl 11: 342-345.
Kusumaningrum ENK, Prasetyo B. 2018. Ulasan Kritis tentang Teori Biogeografi Pulau. Program Studi Biologi, Fakultas Matematika dan Ilmu Pengetahuan Alam, Universitas Terbuka. [Indonesian]

Lourino MC, Fonseca VLI, Roubik DW, Dollin A, Heard T, Aguilar IB, Venturieri GC, Eardley C, Neto PN. 2006. Global meliponiculture: Challenges and opportunities. Apidologie 37: 1-18.

Manarudin MF. 2019. Morfologi dan morfometri lebah tanpa sengat (Apidae: Meliponinae) asal Pandeglang, Banten [Hon. Thesis]. Institut Pertanian Bogor, Bogor. [Indonesian]

Michener CD. 2007. The Bees of The World. Second Edition. The Johns Hopkins Univ. Pr, Baltimore, USA.

Moure JS. 1961. A preliminary supra specific classification of the Old World meliponine bees (Hymenoptera, Apoidea). Studia Entomologica. Revista Intl Entomol 4: 181-242.

Nugroho RB. 2013. Keragaman Sumber Pakan dan Perilaku Mencari Pakan Lebah Trigona iridipennis (Hymenoptera: Apidae) di Gunung Kidul. [Tesis]. Universitas Gadjah Mada, Yogyakarta. [Indonesian]

Rahman A, Das PK, Rajkumari P, Saikia J, Sharmah D. 2015. Stingless bees (Hymenoptera: Apidae: Meliponini) diversity and distribution in India. Intl J Sci Res 4: 77-81.

Rasmussen C, Cameron SA. 2007. A molecular phylogeny of the old world stingless bee (Hymenoptera: Apidae: Meliponini) and the nonmonophyly of the large genus Trigona. Syst Entomol 32:26-39.

Rasmussen C, Michener CD. 2010. The identity and neotype of Trigona laeviceps Smith (Hymenoptera: Apidae). J Kans Entomol Soc 83: 129-133.

Rasmussen C. 2008. Catalog of the Indo-Malayan/Australasian stingless bees (Hymenoptera: Apidae: Meliponini). Zootaxa 1935:1-80.

Roubik DW. 1989. Stingless bee nesting biology. Apidologie 37: 124-143.

Sakagami SF, Inoue T, Salmah S. 1990. Stingless bees of Central Sumatra. Sakagami SF, Ohgushi R, Roubik DW. Editor. Hokkaido Univ Pr, Sapporo (JP), pp 125-137.

Sakagami SF, Inoue T. 1987. Stingless bees of the genus Trigona (subgenus Trigonella) with notes on the reduction of spatha in male genitalia of the subgenus Tetragonula (Hymenoptera: Apidae). Kontyu 55: 610-627.

Sakagami SF. 1978. Tetragonula stingless bees of the Continental Asia and Sri Lanka (Hymenoptera: Apidae). J Fac Agr Hokkaido Univ 21: 165-247.

Salim HMW, Dzulkiply AD, Harrison RD, Fletcher C, Kassim AR, Potts MD. 2012. Stingless bee (Hymenoptera: Apidae: Meliponini) diversity in dipterocarp forest reserves in Peninsular Malaysia. Raffles Bull Zool 60: 213-219.

Schwarz HF. 1939. The Indo-Malayan species of Trigona. Bull AMNH 76: $83-141$.

Smith DR. 2012. Key to workers of Indo-Malayan stingless bees. For use in the Stingless Bees Workshop 1: 1-42.

Suriawanto N. 2016. Keanekaragaman dan Tempat Bersarang Lebah Tak Bersengat (Hymenoptera: Apidae) di Sulawesi Tengah. [Tesis]. Institut Pertanian Bogor, Bogor. [Indonesian]

Syafrizal, Tarigan D, Yusuf R. 2014. Biodiversity and habitat of Trigona at secondary tropical rain forest of Lempake education forest, Samarinda, Kalimantan Timur. Jurnal Teknologi Pertanian 9: 34-38. [Indonesian]

Tej MK, Srinivasan MR, Vijayakumar K, Natarajan N, Kumar SM. 2017. Morphometry analysis of stingless bee Tetragonula iridipennis Smith. Intl J Curr Microbiol App Sci 6: 2963-2970.

Vijayakumar K, Jeyaraaj R. 2014. Taxonomic notes on stingless bee Trigona (Tetragonula) iridipennis Smith (Hymenoptera: Apidae) from India. J Threat Taxa 6: 6480-6484.

Yudha DS, Pratama MZM, Eprilurahman R. 2019. Antlers characterization for identification of deer species (Family Cervidae) in Indonesia. J Trop Biodiv Biotech 4: 97-106. 